\title{
Transverse section of the root of Capsicum species and their taxonomic importance
}

\author{
Aziagba Bibian Okwuchukwu, Okeke Clement Uwabunkeonye, Ezeabara Chinelo Anthonia, \\ Uka Chiedozie Joel, Egboka Toochukwu Praise
}

Department of Botany, Nnamdi Azikiwe University, Awka, Anmbra State, Nigeria

Email address:

aziagbabibian@gmail.com (A. B. Okwuchukwu)

\section{To cite this article:}

Aziagba Bibian Okwuchukwu, Okeke Clement Uwabunkeonye, Ezeabara Chinelo Anthonia, Uka Chiedozie Joel, Egboka Toochukwu Praise. Transverse Section of the Root of Capsicum Species and their Taxonomic Importance. Journal of Plant Sciences.

Vol. 2, No. 5, 2014, pp. 222-225. doi: 10.11648/j.jps.20140205.21

\begin{abstract}
The genus, Capsicum belongs to the family Solanaceae. The transverse sections of the root of five varieties of Capsicum species were investigated. Some common similarities in the pores, ray sizes showing multiserriate and apotrachael parenchyma in some varieties shows close affinity. Variations in the number of vessels and scanty vasicentric paratracheal are suspected to be an influence both by the environment and ecological adaptation as well as genotype. Possession of banded and ,aliform./transverse paratracheal parenchyma by var. Bird eye pepper' and var. 'Nsukka yellow pepper' indicates the two varieties to be more primitive when compared with others .Thus, this research could be important to plant Taxonomist in solving the confusion in the taxonomy of cultivated Capsicum.
\end{abstract}

Keywords: Capsicum Annum, Capsicum Frutecens, Root, Solanaceae

\section{Introduction}

The genus, Capsicum belongs to the family Solanaceae. Members of this family are mostly herbs and twinners with about 70 genera and 2,000 species. (Willis, 1985). Some workers recorded about 85 genera and 2,200 species (Ahmed, 1964, Patel, 1969). Solanaceae is represented in West Africa by 53 species contained in 8 genera (Hutchinson and Dalziel, 1963). Capsicum species are native to the Americans where they have been cultivated for thousands of years by the people of tropical America and now cultivated worldwide(Heiser and Smith,1953).Capsicum species mostly cultivated in southeastern Nigeria includes Capsicum annum Var.'Atarugu', Capsicum.annum Var. 'Otuocha', Capsicum annum Var.'Shombo' curl pepper, Capsicum annum Var.' Nsukka yellow' and Capsicum frutescens Var.Bird eye pepper. There had been considerable confusion regarding the taxonomy of the cultivated peppers. Some early Botanists recognized only one with six botanical varieties or subspecies. Irish, (1898) in his study recognized two species Capsicum annum and Capsicum frutescens; the former has seven botanical varieties. The ease at which domesticated species in particular cross pollinate with each other and the active hybridization of new varieties often for market purposes, has resulted to a baffling range of varieties available making classification an increasingly a difficult task (Pickersgill, 1971). Literature searches by scientist has revealed the importance and implications of anatomical studies in different groups of plants. In view of this, anatomy has been a critical tool to Taxonomist in the classification and separation of taxa (Illor et al; 2011). Anatomical characters are very useful in the determination of relationship in orders and genera and their features have played an increasingly important role in phylogenetic relationships. They include Dioscoreaceae, where certain anatomical features were used in the characterization of D. alata .L. and D.smilacifolia. L. (Edeoga, 2002). In Costaceae, where differences in features of vegetative anatomy suggested a separate specific status for C. afer and C. lucanusianus as opposed to the conspecific treatment given to them by previous researchers (Edeoga and Okoli, 1997). In Leguminosae-Caesalpinoideae, where the nature of unicellular and multicellular trichomes are described in certain species of Senna Tourn ex Mill and S. hirsuta was reported to be diagonostic in acquisition of these two types of trichomes. (Edeoga and Osawe, 1996). Type, size, shape, stellar patterns, vascular bundles, rays, parenchyma, epidermal and phloem cells are some of the basic anatomical characters of well established taxonomic value. (Sharma, 1993; Pandley, 2007).. 
Prior to this ,the transverse section (T,S)of the root of five Capsicum species cultivated in Southeastern Nigeria was investigated to provide a useful information, with the view to document the anatomical features of these Capsicum species which will help to understand the intra and interspecific relationship existing in them.

\section{Materials and Methods}

The root of the Capsicum varieties Var.'Atarugu',Var ' Otuocha',Var 'Shombo' Var.'Nsukka yellow' and Var.' Bird eye pepper' was collected from the Botanical garden at Nnamdi Azikiwe University Awka at their matured stage.The samples was authenticated at the Department of Botany Nnamdi Azikiwe University Awka by a plant Taxonomist Prof. C,U, Okeke.

\section{Anatomical Analysis}

The roots of Capsicum varieties under study were collected in vials containing formaldehyde, glacial acetic acid and alcohol in the ratio of 1:1:8 respectively. The specimens were dehydrated in ethanol series (30\% 50\% 70\% and 95\%) each for 2 hours. Complete dehydration of specimens was effected by storing the specimens in absolute (99.6\%) ethanol overnight. The specimens were then cleared in $3: 1,1: 1$ and 1:3 ethanol/chloroform each for 3 hours. Wax was melted at $70{ }^{\circ} \mathrm{c}$ in an oven. The cleared specimens were then put in molten anatomical wax and alcohol and allowed to stay at $70^{\circ} \mathrm{c}$ for 24 hours for effective infiltration of wax into the specimen to replace the chloroform which was gradually lost by evaporation. Embedding was carried out after infiltration. This was done by smearing the inside of clean molds with glycerin, pouring the molten wax into the molds with appropriate orientation in a position suitable for the type of section to be cut. The Wax in the mould was allowed to cool into a block. The wax blocks were freed from the mould stuck on wooden holder and labeled, pending sectioning.

Wax blocks already freed from the holder and trimmed were affixed on the sledge microtome and sectioned at 15-20 microns thickness. The thin sections were fixed on clean slides already smeared with a thin film of egg albumen. They were stretched by passing them over hot plate. This also made them to become attached to the slides. Slides bearing sections were arranged in a slide rack and placed in an oven at $70^{\circ} \mathrm{c}$ to melt off wax from the sections. This Lasted for 12 hours.

For staining, sections were dehydrated by passing slides across xylene and xylene/absolute ethanol series (3:1, 1:1 and 1:3 v/v), absolute ethanol, 95, 70,50and 30\% ethanol. Slides were briefly immersed in water, then stained with $0.1 \%$ alcian blue and counter stained with $1 \%$ safranin. Stained slides were rinsed briefly in tap water dehydrated through the ethanol series and cleared across the xylene /absolute ethanol series.

Mounting was carried out by placing one drop of Canada balsam on a clean slide and carefully covering the sections with the cover slip in a way that the Canada balsam spread and covered the specimen sections overlaid by the cover slip. They were studied and photomicrographs taken.

\section{Results}

The anatomical characters of the five varieties were presented in Plates 1-5

Transverse section of the root of 'Atarugu'; showed Presence of one layer of epidermis and an angular collenchyma and parenchyma cells having intercellular spaces. Ring pores were seen indicating growth. The growth rings are formed in diffuse porous. The shapes of the

pores were round and the arrangements were exclusively solitary. Parenchyma apotracheal were in diffuse aggregates while parenchyma paratracheal types were scanty paratracheal and vasicentric. The ray sizes were more than half width of pores and storied

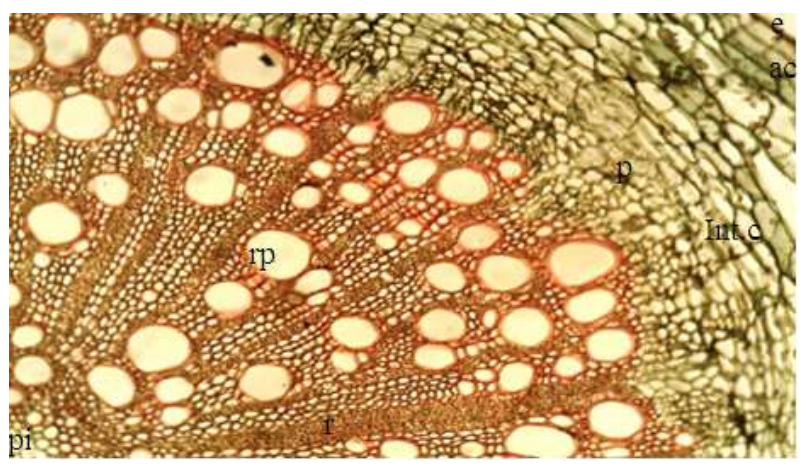

Plate 1. Transverse section of root of Var. 'Atarugu' $\times 100$.

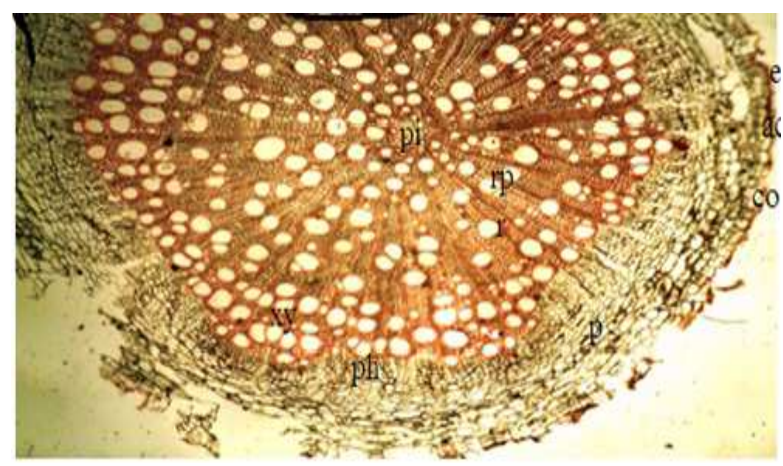

Plate 2. Transverse section of the root of 'Otuocha'. $\times 100$

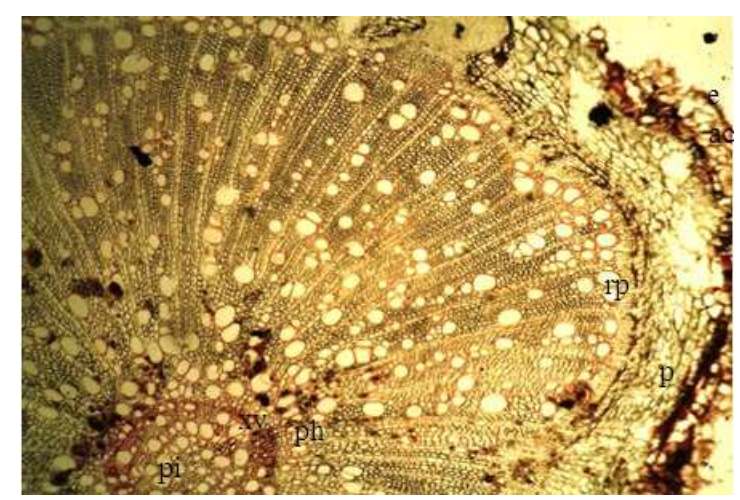

Plate 3. Transverse section of" Shombo" curl pepper root. $\times 100$ 
The section showed the presence of one layer of epidermis; an angular collenchyma, cork cell and the cortex between the vascular bundle and the epidermis were visible. There were primary xylem and conducting xylem and phloem. The presence of semi ring pores indicates growth rings of various sizes in a diffuse form. Pore arrangements were exclusively solitary. Apotracheal parenchyma was in diffuse aggregates. The paratracheal parenchyma were scanty and vasicentric. Sizes of the rays were in aggregates (transverse), nonstoried and multiserriate. There were presence of xylem and phloem alternating with each other. Tyloses were visible inside the pores with greenish and reddish colour

There was the presence of one layer of epidermial cell. An angular collenchyma and parenchyma cells. Ring pores were visible indicating growth. Growth rings were formed by terminal parenchyma. Shapes of the pores were round. Arrangements of the pores were in radial or oblique. Apotracheal parenchyma types were bonded while paratracheal parenchyma types were scanty and vasicentric. Ray sizes were in aggregates (transverse) and storied .

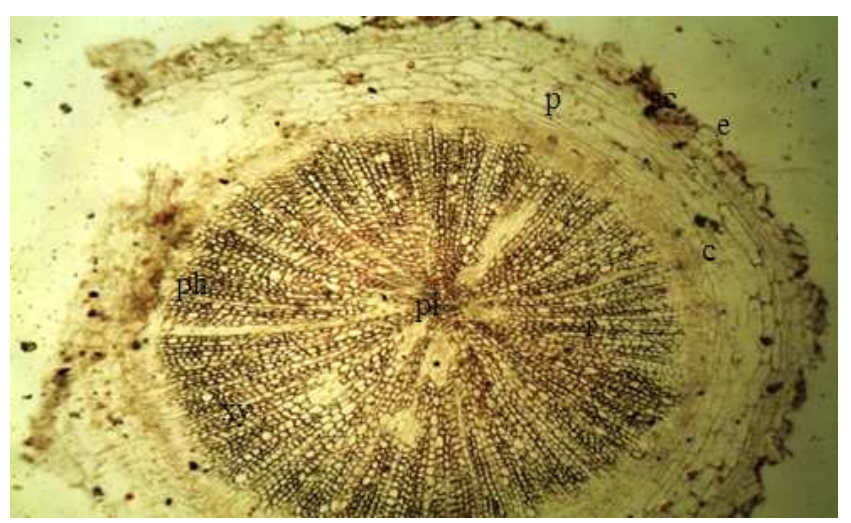

Plate 4. Transverse section of the root of Nsukka yellow pepper $\times 100$

This showed the epidermal layer as one layer, and an angular collenchyma. Ring pores revealed growth. The pores were round in shape, and arranged in radial multiples. Apotrachael parenchyma types were in diffuse aggregate. Paratrachael parenchyma showed aliform confluent type. Rays were in aggregate and storied.

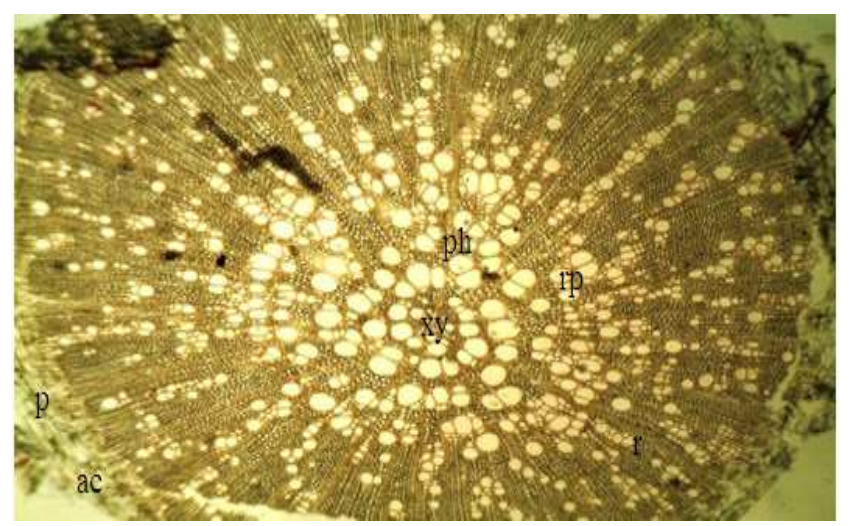

Plate 5. Transverse section of the root of Capsicum frutescensVar.Bird eye pepper.
This showed the presence of tearing epidermis. Presence of terminal parenchyma. The ring pores indicates growth. The pores were angular in shape and arranged in clusters. The parenchyma apotraechal were bonded. Paratracheal parenchyma were bonded. Sizes of the rays were transverse and storied.

N.B.These alphabets represents the labelling of the structures of cells in Plates 1-5 thus e-epidermis, bs-bundle sheet extension, xy-xylem, st-starch stain, spt-spongy tissue,palisade tissue, ph-phloem, p-parenchyma ,pi-pith, rrays, co.c-cork cell, r.p pores, int.c-intercellular spaces, rigridges, f-furrows, $\mathrm{c}$ - cambium, a- angular. $\mathrm{C}$-collenchyma

\section{Discussion}

The results obtained from this study revealed that there are some similarities in the

anatomical features of Capsicum varieties in plates 1,2,3, 4 and 5 The root organization in the five varieties show similar organisation in the epidermis, with one layer and an angular collenchyma. Pores are angular (Plate 5) exclusively solitary (Plate 2) while pores of other varieties have round shape. Apotracheal parenchyma of some varieties occur in diffuse aggregate (Plates 4, 1 and 2) while others have round shape.. Paratracheal parenchyma are scanty in others, banded in plate 5, and aliform/confluent in plate 4 . This is in agreement with the earlier work of (Cosa et al., 1998) on Solanum species revealing similar root organization in solanaceae. Ray sizes are in aggregate/transverse (Plates 4, 5, 3 and 2), more than half width in Plate 1. Vessels in Plate 2 have tyloses which are greenish and reddish in colour revealing organic deposits in the cells. This is in agreement with the report of an earlier work (Uju et al., 1999). The cell structures in all the Plates have xylem and phloem fibers alternating with one another. There are variations in the number of vessels and the position of the rays. These differences strengthen the reliability of anatomical characters in systematic botany as stated by Ayensu (1970) in Dioscorea rotundata, and Dioscorea cayenensis Lam., Mbagwu and Edeoga (2006) in Vigna species, Edeoga (2002) in Dioscorea species, Edeoga and Okoli (1997) in Costaceae etc. The similarities as revealed were more accurate, while variations were tangential or negligible to merit their separation into species. variations observed can only separates plants into varieties or cultivars of species.

\section{Conclusion}

Based on these findings, the five varieties have close relationship revealed in their homodorminant characters which strengthens their affinity relationship while some of the variations in characters can be a hybrid. 'Nsukka yellow', 'Atarugu' ,'Shombo curl' and 'Otuocha' are more closely related while 'African bird eye' and 'Shombo curl' has moderate relationship. 'Atarugu' and 'Otuocha' are the most closely related. Therefore, root anatomy could be an important tool to plant Taxonomist in classification of 
Capsicum species and in solving the problem of hybrid breakdown which is currently affecting this species.

\section{References}

[1] Aimed, K.J., 1964. On stomatal abnormalities in Solanaceae. Sci. Cult., 30: 350-361.

[2] Ayensu, E.S., 1970. Comparative anatomy of Dioscorea rotundata Poir and Dioscorea cayenensis LAM. J. Linn. Soc. Bot. Suppl., 1: 127-136.

[3] Cutler, D.F., 1978. Applied Plant Anatomy. Longman, London, pp: $125-128$.

[4] Edeoga, H.O. and B.E. Okoli, 1995. Histochemical studies in the leaves of some Dioscorea L. (Dioscoreaceae) and the taxonomic importance. Feddes Rep., 106: 113-120.

[5] Edeoga, H.O. and B.E. Okoli, 1997. Anatomy and systematics in the Costus afer, C. lucanusianus complex (Costaceae). Acta Phytotax. Geobot., 45: 151-158.

[6] Edeoga, H.O. and I.O. Osawe, 1996. Cuticular studies of some Nigerian species of Senna Tourn. Ex Mill. (Syn Casia Tourn. Ex. L): Leguminosae Caesalpinoideae. Acta Phytotax Geobot., 47: 41-46.

[7] Edeoga, H.O., 2002. Anatomical studies on the roots of some Dioscorea L. species (Dioscoreaceae). Afr. J. Root Tuber. Crop, 5: 33-37.

[8] Heiser, C.B. and Smith, P.C. (1953b). The cultivated Capsicum. Economic Botany. 1: 214 -227.
[9] Hutchinson, J. and J.M. Dalziel, 1963. Flora of West Tropical Africa. 2nd Edn., Crown Agents for Overseas Government and Administration, London, ISBN: 0-85592-020-3, pp: 23-27.

[10] Irish, H.C (1898). A revision of the genus Capsicum with species reference to Garden varieties. Rep.Missiouri Botany Garden.9:53-110.

[11] Mbagwu, F.N. and H.O. Edeoga, 2006. Anatomical studies on the root of some Vigna savi species (LeguminosaePapilionoideae). Agric. J., 1: 8-10|

[12] Mbagwu, F.N., 2005. Taxonomic studies on some Vigna savi species (Leguminosae-Papilionoideae). Ph.D Thesis, Michael Okpara University of Agriculture.

[13] Metcalfe, C.R. and L. Chalk, 1950. Anatomy of the Dicotyledons. Vol. 2, Clarendon Press, USA.

[14] Okoli, B.E., 1987. Anatomical studies in the leaf and probract of Telferia Hooker (Curcurbitaceae). Feddes Repert, 98: 231236.

[15] Okoli, B.E., 1988. On the probable function and taxonomic value of calcium oxalate crystals in curcurbitaceae. Feddes Rep., 99: 139-142.

[16] Patel, J.D., 1969. Studies in stomata of Chilli and Brinjal. Ann. Bot., 35: 1197-1203.

[17] Pickersqill, B. (1971). Relationship between woody and cultivated forms in some species of chile peppers (Genus Capsicum) Evolution Vol. 25 No 4.;683-691 